\title{
Development of an Amperometric Enzyme Electrode based on Poly(o-Phenylenediamine) for the Determination of Total Cholesterol in Serum
}

\author{
Derya Koyuncu Zeybek, *,a Bülent Zeybek, ${ }^{a}$ Nuran Özçiçek Pekmez, ${ }^{b}$ Şule Pekyardımct ${ }^{c}$ and Esma Kllıç \\ ${ }^{a}$ Department of Chemistry, Faculty of Arts and Sciences, Dumlupınar University, Kütahya, Türkiye \\ ${ }^{b}$ Department of Chemistry, Faculty of Science, Hacettepe University, Ankara, Türkiye \\ ${ }^{c}$ Department of Chemistry, Faculty of Science, Ankara University, Ankara, Türkiye
}

\begin{abstract}
Um eletrodo enzimático amperométrico baseado em polímero foi preparado para detecção amperométrica de colesterol livre. Inicialmente, o filme polimérico poli (o-fenilenodiamina) (PoPD) foi eletropolimerizado no meio acetonitrila-água contendo o monômero $o$-fenilenodiamina $(o \mathrm{PD})$ e ácido canforsulfônico em eletrodo de Pt através da técnica de voltametria cíclica. A enzima oxidase colesterol foi imobilizada sobre a superfície do eletrodo Pt/PoPD. A determinação de colesterol foi realizada por maio do monitoramento da corrente de oxidação de $\mathrm{H}_{2} \mathrm{O}_{2}$ produzido enzimaticamente a $+0,7 \mathrm{~V}$ vs. $\mathrm{Ag} / \mathrm{AgCl}$. A concentração da solução tampão, o valor de $\mathrm{pH}$ e a temperatura de trabalho otimizados foram $0,05 \mathrm{~mol} \mathrm{~L}^{-1}, 7,5$ and $40{ }^{\circ} \mathrm{C}$, respectivamente. $\mathrm{O}$ intervalo de trabalho do eletrodo de enzima para colesterol foi $9,8 \times 10^{-3}-11 \mu \mathrm{mol} \mathrm{L}^{-1}$ e tempo de resposta $150 \mathrm{~s}$. Os efeitos de possíveis interferências presentes em amostras de soro em resposta ao eletrodo de enzima foram examinados. A determinação do colesterol total em amostras de soro foi realizada usando o eletrodo de enzima $\mathrm{Pt} / \mathrm{PoPD} / \mathrm{ChOx}$ proposto e os resultados foram em bom acordo com os obtidos pelo método espectrofotométrico.
\end{abstract}

A polymer-based amperometric enzyme electrode ( $\mathrm{Pt} / \mathrm{PoPD} / \mathrm{ChOx})$ was prepared for the amperometric detection of free cholesterol. Firstly, poly (o-phenylenediamine) (PoPD) polymer film was prepared in acetonitrile-water medium containing $o$-phenylenediamine $(o P D)$ monomer and $( \pm$ )-10-camphorsulfonic acid (HCSA) on Pt electrode by the use of cyclic voltammetry technique. Cholesterol oxidase ( $\mathrm{ChOx}$ ) enzyme was immobilized onto $\mathrm{Pt} / \mathrm{PoPD}$ electrode surface. The determination of cholesterol was performed via monitoring of the oxidation current of enzymatically produced $\mathrm{H}_{2} \mathrm{O}_{2}$ at $+0.7 \mathrm{~V} v \mathrm{~s}$. $\mathrm{Ag} / \mathrm{AgCl}$. Optimum buffer concentration, $\mathrm{pH}$ and working temperature were found as $0.05 \mathrm{~mol} \mathrm{~L}^{-1}, 7.5$ and $40{ }^{\circ} \mathrm{C}$, respectively. The working range of enzyme electrode to cholesterol was $9.8 \times 10^{-3}-11 \mu \mathrm{mol} \mathrm{\textrm {L } ^ { - 1 }}$ and response time $150 \mathrm{~s}$. The effects of possible interferences present in serum samples on response of enzyme electrode were examined. The determination of total cholesterol in serum samples was performed by using proposed $\mathrm{Pt} / \mathrm{PoPD} / \mathrm{ChOx}$ enzyme electrode and results were in good agreement with those obtained by spectrophotometric method.

Keywords: biosensor, cholesterol, poly(o-phenylenediamine), serum, hydrogen peroxide

\section{Introduction}

Cholesterol and its fatty acid esters are structural component of mammalian cell membranes and are also precursors of various biological constituents such as, vitamin $\mathrm{D}$, steroid hormones and bile acids. ${ }^{1,2}$ Although cholesterol is a significant and essential molecule, high cholesterol levels in blood are related to hypertension, myocardial infarction, cerebral thrombosis and

*e-mail: derya_koyuncu@yahoo.com arteriosclerosis. ${ }^{3,4}$ Since the concentration of total cholesterol in blood is important for diagnosis and prevention of these diseases, various methods such as spectrophotometry and chromotography have been developed for determination of cholesterol..$^{5-11}$ However, these methods are usually laborious, expensive, time-consuming and/or complicated. An alternative method of determination of cholesterol is amperometric enzyme electrodes which allow rapid, accurate, low-cost and sensitive analysis. ${ }^{3,12}$ Various types of amperometric enzyme electrodes have been reported for free cholesterol determination. ${ }^{13-23}$ 
Cholesterol oxidase (ChOx), in the presence of molecular oxygen, catalyzes the oxidation and isomerization of cholesterol by forming cholest-4-en-3-one and hydrogen peroxide as shown in equation $1 .^{2}$

Cholesterol $+\mathrm{O}_{2} \stackrel{\text { Chox }}{\longrightarrow}$ Cholest-4-en-3-on $+\mathrm{H}_{2} \mathrm{O}_{2}$

The oxidation current of hydrogen peroxide can be detected at applied potential and the current is proportional with the concentration of hydrogen peroxide and thus the concentration of cholesterol in the samples. ${ }^{4,15}$

$\mathrm{H}_{2} \mathrm{O}_{2} \longrightarrow \mathrm{O}_{2}+2 \mathrm{H}^{+}+2 \mathrm{e}^{-}$

Since oxidation of hydrogen peroxide requires high working potential such as $+0.7 \mathrm{~V}$ ( vs. $\mathrm{Ag} / \mathrm{AgCl}$ ), other electroactive substances present in biological samples are also oxidized and interfere the response..$^{24,25}$ Basically, two options are available to avoid the effects of interferences. One is to lower the applied potential by using electron transfer mediators ${ }^{26-29}$ and the other one is to employ a permselective polymer films in order to decrease the interferences. ${ }^{30}$

In amperometric enzyme biosensors, polymer films prepared by electropolymerization which used as immobilization matrixes have been frequently employed. ${ }^{31}$ Electropolymerization is often carried out in aqueous or non-aqueous solution containing monomer by using chronoamperometric or cyclic voltammetric techniques. Unlike various methods that used in development a biosensor, electropolymerization presents many advantages such as reproducibility, thickness control and the uniformity of the polymer film and give permission to simple preparation of polymer film modified electrodes. ${ }^{32}$ The conducting polymers such as polypyrrole, ${ }^{3,33-35}$ polyaniline ${ }^{17,36}$ and polythiophene ${ }^{37}$ have been widely used for the biosensors development. These polymers have a high conductivity, stability and also amount of biomaterial can be controlled during electropolymerization process. ${ }^{32}$ In addition, nonconducting polymers such as polyphenol and its derivates, polyphenylenediamines and overoxidized polypyrrole also have been used as an immobilization matrix for enzymes. Since nonconducting polymers are very thin because of their self-limited growth, the response of amperometric biosensor based on nonconducting polymer to their substrate can be resembled to that of an unmodified electrode. They also have advantages, including permselectivity and reproducibility, and thus can eliminate possible interferences such as ascorbate, uric acid, acetaminophen, urea, etc. present in real samples. Polyphenylenediamines have been extensively reported for development a biosensor because of the excellent permselective properties. Since for many oxidase-based amperometric biosensors, detections of substrates are carried out via monitoring enzymatically produced hydrogen peroxide, polymer films should be highly permeable to hydrogen peroxide and efficiently eliminate the interference species. Ortho isomer poly(o-phenylenediamine) of polyphenylenediamines is the most studied form, and is the subject of the present study. ${ }^{38}$ Poly (o-phenylenediamine) films have been widely used on amperometric glucose, ${ }^{26,30,39-45}$ phenol, ${ }^{46} \mathrm{~L}-1 y \operatorname{sine} \mathrm{e}^{47,48}$ and ethano ${ }^{49}$ biosensor for elimination of interference from electroactive species present in real samples. A literature search revealed that there were no reports of biosensor prepared by the polymerization conditions used in this study. In various studies, working electrodes were coated by poly (o-phenylenediamine) film using aqueous solution of monomer as an outer layer for elimination interferences. ${ }^{38,50}$ In cholesterol biosensors, poly (o-phenylenediamine) films were also used for elimination interference and determination of cholesterol in human serum could not be performed by using prepared biosensor. ${ }^{12,51}$ However, in the present study, poly $(o-$ phenylenediamine) film is composed both permselective membrane and immobilization matrix for enzyme.

In the present study, amperometric cholesterol enzyme electrode was developed and optimizations of working conditions were carried out. For this purpose, cholesterol oxidase (ChOx) enzyme was immobilized on the electrochemically synthesized poly(o-phenylenediamine) polymer films using glutaraldehyde. It was concluded that polymeric film reduced the effects of interferent substances such as uric acid, L-ascorbic acid, urea, etc. present in serum. The amounts of total cholesterol in serum samples were determined and $>0.998$ correlation was obtained between proposed enzyme electrode results and those obtained by spectrophotometric method.

\section{Experimental}

\section{Apparatus and reagents}

Electrochemical experiments were performed with IVIUMSTAT electrochemical analyzer (Ivium Techonologies, Netherlands) using a three-electrode cell stand (Bioanalytical Systems, Inc., USA). In the electropolymerization studies, working electrode was platinum disk electrode (4 $\mathrm{mm}$ diameter). A silver wire in contact with $0.01 \mathrm{~mol} \mathrm{~L}^{-1} \mathrm{AgNO}_{3}$ and $\mathrm{Pt}$ foil were used as the reference electrode and counter electrode, respectively. The $0.01 \mathrm{~mol} \mathrm{~L}^{-1} \mathrm{AgNO}_{3}$ solution in the reference electrode was prepared in acetonitrile containing 
$0.1 \mathrm{~mol} \mathrm{~L}^{-1}$ tetrabutylammonium perchlorate (TBAP) as the supporting electrolyte. In amperometric detection experiments, polymer film coated Pt disc electrode or enzyme immobilized polymer coated Pt disc electrode were used as working electrode. Reference and counter electrodes were $\mathrm{Ag} / \mathrm{AgCl}$ electrode (BAS MF 2052) and Pt wire (BAS MW 1034), respectively. The $\mathrm{pH}$ values of the buffer solutions were measured with ORION Model 1906 D $720 \mathrm{~A} \mathrm{pH} /$ ion meter (Thermo Scientific, USA). Temperature control was achieved with Grant LTD GG thermostat (Grant Instruments, UK). Scanning electron micrographs were taken with a Jeol JSM-7000F field emission scanning electron microscope (FESEM) (Jeol Ltd., Japan). All solutions were prepared with deionized water of resistivity not less than $18 \mathrm{M} \Omega \mathrm{cm}$ taken from an Elga Purelab Classic water purification system (Veolia Water Systems Ltd., UK).

Cholesterol oxidase from Pseudomonas $s p$. (2.4 $\mathrm{U} \mathrm{mg}^{-1}$ EC 1.1.3.6), water soluble cholesterol, ascorbic acid, urea and uric acid were all purchased from Sigma. Cholesterol esterase from porcine pancreas $\left(44.4 \mathrm{U} \mathrm{mg}^{-1}\right.$ EC 3.1.1.13), TBAP, $\mathrm{AgNO}_{3}$, paracetamol and creatinine were supplied from Fluka. $o$-Phenylenediamine monomer, ( \pm )-10-camphorsulfonic acid and $\mathrm{Li}_{2} \mathrm{CO}_{3}$ were obtained from Aldrich. Acetonitrile, hydrogen peroxide, di-sodium monohydrogen phosphate heptahydrate and sodium dihydrogen phosphate dihydrate were purchased from Riedel de Haën.

\section{Electropolymerization process}

The working electrodes were polished by alumina particles (sizes $0.05 \mu \mathrm{m}$ ) thoroughly and ultrasonically cleaned in ethanol and double distilled water sequentially. The Pt disk electrode was immersed in acetonitrile (94\%)-water (6\%) mixture containing $0.1 \mathrm{~mol} \mathrm{~L}^{-1} o$-phenylenediamine (o-PD) and $0.2 \mathrm{~mol} \mathrm{~L}^{-1}( \pm)$-10-camphorsulfonic acid (HCSA). The solution was purged with argon in order to remove the oxygen. The electropolymerization of $o$-phenylenediamine was performed by potential cycling between -0.4 and $+2.2 \mathrm{~V} v s$. $\mathrm{Ag} / \mathrm{Ag}^{+}$at a scan rate $0.025 \mathrm{~V} \mathrm{~s}^{-1}$ with 50 cycles. The obtained $\mathrm{Pt} / \mathrm{PoPD}$ electrode was immersed into acetonitrile and dried at room temperature.

\section{Preparation of enzyme electrode}

$\mathrm{Pt} / \mathrm{PoPD}$ electrode was dipped into $250 \mu \mathrm{L}$ cholesterol oxidase (ChOx) $\left(2.4 \mathrm{U} \mathrm{mL}^{-1}\right)$ solution containing $5 \mu \mathrm{L}$ glutaraldehyde $(25 \%)$ for $12 \mathrm{~h}$ at $+4{ }^{\circ} \mathrm{C}$ for immobilization of enzyme molecules. The prepared $\mathrm{Pt} / \mathrm{PoPD} / \mathrm{ChOx}$ enzyme electrode was rinsed with buffer solution in order to remove any unbounded enzyme molecules. The enzyme electrode was kept in refrigerator at $+4{ }^{\circ} \mathrm{C}$ when it was not in use.

\section{Amperometric measurements}

All amperometric measurements were performed in phosphate buffer solution $\left(0.05 \mathrm{~mol} \mathrm{~L}^{-1} \mathrm{pH} 7.5\right)$. In this study, the determination of free cholesterol was based on electrooxidation of $\mathrm{H}_{2} \mathrm{O}_{2}$ at $+0.7 \mathrm{~V}$ ( vs. $\mathrm{Ag} / \mathrm{AgCl}$ ) at the surface of polymer film electrode therefore, it was first investigated whether $\mathrm{Pt} / \mathrm{P} o \mathrm{PD}$ electrode was sensitive to $\mathrm{H}_{2} \mathrm{O}_{2}$ or not. For this purpose, $5.0 \mathrm{~mL}$ of buffer solution were added to the electrochemical cell and a steady-state background current was allowed to decay at a constant value at $+0.7 \mathrm{~V}(v s$. $\mathrm{Ag} / \mathrm{AgCl})$. Then aliquots of hydrogen peroxide solution were added to electrochemical cell and the current responses were recorded at $+0.7 \mathrm{~V}$ (vs. $\mathrm{Ag} / \mathrm{AgCl}$ ). The current values were plotted against hydrogen peroxide concentration in order to the determination of the sensitivity. The amperometric detection of free cholesterol was carried out at $+0.7 \mathrm{~V} v s$. $\mathrm{Ag} / \mathrm{AgCl}$ via electrochemical oxidation, at the $\mathrm{Pt} / \mathrm{P} o \mathrm{PD} / \mathrm{ChOx}$ electrode, of hydrogen peroxide generated in enzymatic reaction. First, enzyme electrode was equilibrated in phosphate buffer solution at $+0.7 \mathrm{~V}(v s . \mathrm{Ag} / \mathrm{AgCl})$ until a constant current was obtained. Then aliquots of cholesterol solution were added to electrochemical cell and the current responses were recorded.

\section{Results and Discussion}

In this study, a new amperometric cholesterol enzyme electrode based on PoPD was prepared. The hydrogen peroxide sensitivity of $\mathrm{Pt} / \mathrm{P} o \mathrm{PD}$ electrode, surface characterization, optimum working conditions and performance factors of the $\mathrm{Pt} / \mathrm{PoPD} / \mathrm{ChOx}$ electrode and effects of interferences were studied and results were given below. The determination of total cholesterol in serum samples was also performed.

\section{Preparation of PoPD film}

The optimization studies of electropolymerization of $o$-phenylenediamine (o-PD) were conducted in elsewhere. ${ }^{52}$ In that study, optimization parameters such as potential range, percentage of water in polymerization solution and concentration of $o$-PD were evaluated and these conditions were used in present study. The electropolymerization of $o$-PD upon Pt electrode surface were performed by cyclic voltammetry between -0.4 and $2.2 \mathrm{~V}$ at a scan rate 
$0.025 \mathrm{~V} \mathrm{~s}^{-1}$ with 50 cycles and the cyclic voltammogram obtained during electropolymerization is given in Figure 1. In the first scan, the anodic current started increasing at about $0.15 \mathrm{~V}$ and reached to maximum value at $1.8 \mathrm{~V}$, which corresponds to the oxidation of protonated $o \mathrm{PD}$ monomer. This irreversible peak shifted to negative potential and its intensity decreased regularly during subsequent scans, indicating that the polymeric film was formed and formation of PoPD film blocked further access of monomers to Pt electrode surface. . $^{4,47,50}$

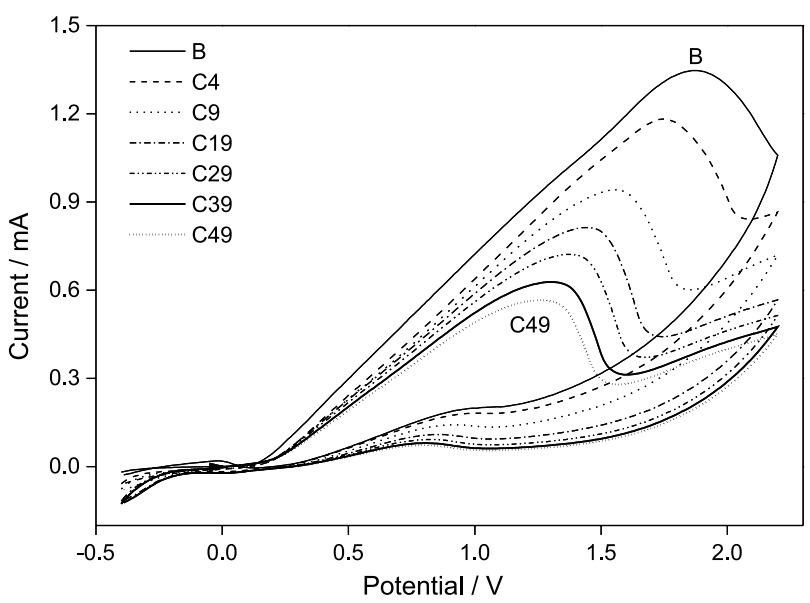

Figure 1. Cyclic voltammograms obtained during electropolymerization of $o$-PD on Pt electrode in acetonitrile (94\%)-water (6\%) mixture containing $0.1 \mathrm{~mol} \mathrm{~L}^{-1} o$-phenylenediamine (o-PD) and $0.2 \mathrm{~mol} \mathrm{~L}^{-1}$ $( \pm)$-10-camphorsulfonic acid (HCSA). Conditions: potential cycling range of $-0.4-2.2 \mathrm{~V}$, scan rate of $0.025 \mathrm{~V} \mathrm{~s}^{-1}$ and 50 cycles.

The hydrogen peroxide sensitivity of $\mathrm{Pt}$ and $\mathrm{Pt} / \mathrm{PoPD}$ electrodes

In this study, the determination of free cholesterol was based on electrooxidation of $\mathrm{H}_{2} \mathrm{O}_{2}$ at $+0.7 \mathrm{~V}$ (vs. $\mathrm{Ag} / \mathrm{AgCl})$ at the surface of polymer film electrode therefore, it was first investigated whether $\mathrm{Pt} / \mathrm{PoPD}$ electrode was sensitive to $\mathrm{H}_{2} \mathrm{O}_{2}$ or not. The same experiment was also performed for Pt disk electrode for comparison. The amperometric responses of $\mathrm{Pt}$ and $\mathrm{Pt} / \mathrm{PoPD}$ electrodes as a function of $\mathrm{H}_{2} \mathrm{O}_{2}$ concentration were shown in Figure 2A. It can conclude that $\mathrm{PoPD}$ film has composed a permeable membrane against $\mathrm{H}_{2} \mathrm{O}_{2}$ and sensitivity obtained with $\mathrm{Pt} / \mathrm{Po}$ PD electrode to $\mathrm{H}_{2} \mathrm{O}_{2}$ was as same as those obtained with Pt electrode. In conclusion, $\mathrm{Pt} / \mathrm{PoPD}$ electrode can be used as an immobilization matrix for the development of the biosensor based on oxidase enzymes. The response of amperometric electrodes based on non-conducting polymers like PoPD can be equated to that uncovered electrode. . $^{5,54}$

The electrochemical behavior of polymer film in the presence and absence of hydrogen peroxide was examined
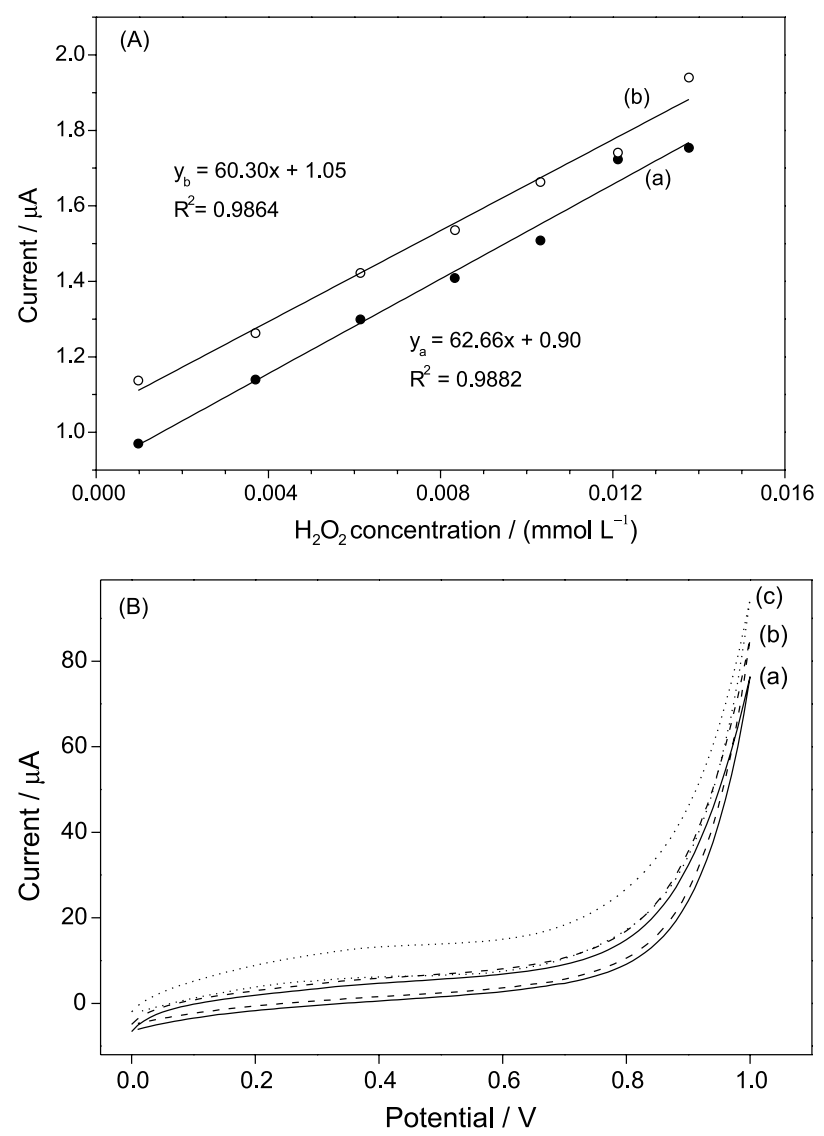

Figure 2. (A) Amperometric response of $\mathrm{Pt}$ (a) and $\mathrm{Pt} / \mathrm{Po} \mathrm{PD}$ (b) electrodes as a function of $\mathrm{H}_{2} \mathrm{O}_{2}$ concentration in $0.05 \mathrm{~mol} \mathrm{~L}^{-1}$ phosphate buffer (pH 7.5) at +0.7 V vs. Ag/AgCl. (B) Cyclic voltammograms of Pt/PoPD electrode in the absence (a), presence of $2.0 \times 10^{-4} \mathrm{~mol} \mathrm{~L}^{-1}$ (b) and $1.1 \times 10^{-3} \mathrm{~mol} \mathrm{~L}^{-1}(\mathrm{c})$ of hydrogen peroxide.

by the cyclic voltammetry. As can be seen in Figure 2B, adding hydrogen peroxide to the PBS caused an increase in the oxidation current.

\section{Characterization of the electrodes with SEM}

The physical morphology of polymer film has significant role in the immobilization of the enzyme and reflects the performance of the enzyme electrode. The morphologies of $\mathrm{PoPD}$ and $\mathrm{PoPD} / \mathrm{ChOx}$ films were characterized by field emission scanning electron microscopy (FESEM). A typical SEM micrograph of Pt/PoPD (Figure 3a) displays a smooth and uniform morphology. The cracks observed on polymer film surface are resulted from the nature of PoPD polymer film. ${ }^{55,56}$ As seen in Figure 3b, the SEM micrograph of the ChOx immobilized onto $\mathrm{Pt} / \mathrm{PoPD}$ electrode surface exhibits covered and globular structure indicating immobilization of enzyme.

$\mathrm{Pt} / \mathrm{PoPD} / \mathrm{ChOx}$ enzyme electrode was used for determination of free cholesterol. Optimization of working condition such as buffer concentration, buffer $\mathrm{pH}$ and 

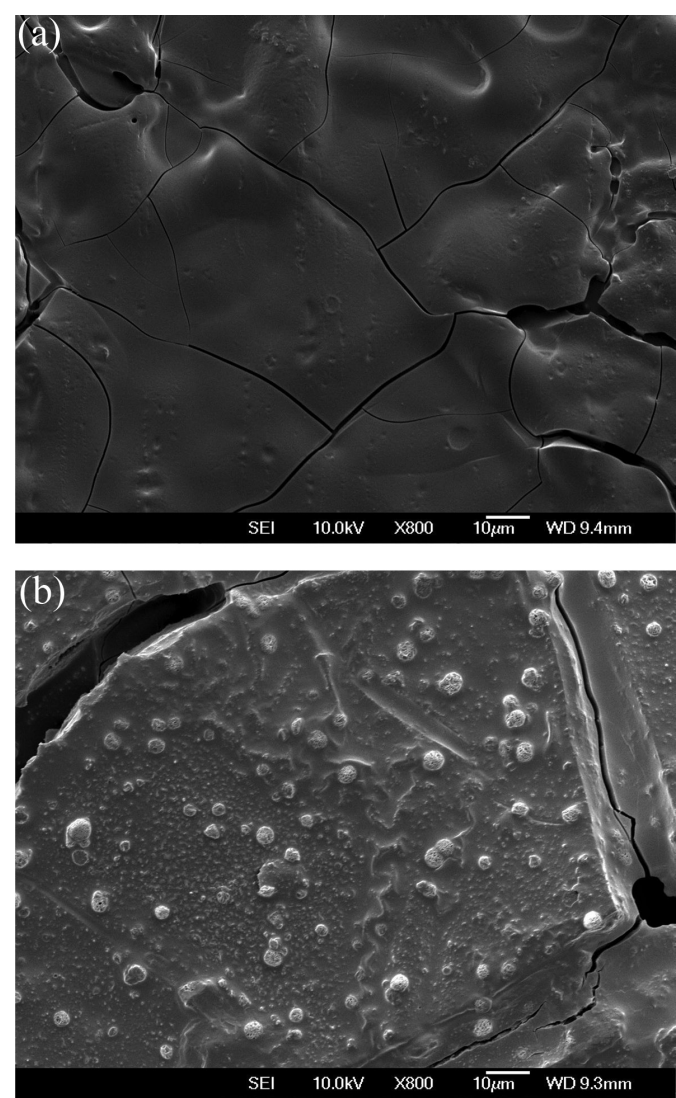

Figure 3. SEM micrographs of (a) $\mathrm{Pt} / \mathrm{PoPD}$ electrode and (b) $\mathrm{Pt} / \mathrm{P} o \mathrm{PD} / \mathrm{ChOx}$ enzyme electrode.

temperature, performance factors such as response time, reusability and reproducibility were also evaluated. Besides the effects of substrate concentration and interferences on amperometric response were studied. Total cholesterol in serum was analyzed by using proposed enzyme electrode and results were presented below.

\section{Effects of buffer concentration and $\mathrm{pH}$}

Current-cholesterol concentration plots of the $\mathrm{Pt} / \mathrm{PoPD} / \mathrm{ChOx}$ enzyme electrode were obtained in four different phosphate buffer concentrations $\left(0.05-0.2 \mathrm{~mol} \mathrm{~L}^{-1}\right)$ at a $\mathrm{pH}$ value of 7.5. The slopes (sensitivity) of the calibration curves were plotted against the buffer concentration. Sensitivity values diminished while moving towards increased buffer concentration and optimum buffer concentration was found as $0.05 \mathrm{~mol} \mathrm{~L}^{-1}$. This result is in good agreement with that of the polymer based cholesterol biosensors. ${ }^{17,19,21,36}$

The $\mathrm{pH}$ value has important effects on enzyme activity and thus enzyme activity should change with the $\mathrm{pH}$ of buffer. The sensitivities of $\mathrm{Pt} / \mathrm{PoPD} / \mathrm{ChOx}$ enzyme electrode as function of $\mathrm{pH}$ are shown in Figure 4. The sensitivity increased from $\mathrm{pH} 6.0$ to 8.0 and the highest sensitivity was obtained at $\mathrm{pH}$ 8.0. However, sensitivities in the range of $\mathrm{pH}$ 7.0-8.0 were not different from each other and at $\mathrm{pH} 7.5$ linear working range was relatively broader than others (not shown). For this reason, $\mathrm{pH} 7.5$ which is close to that of the optimum $\mathrm{pH}$ of free cholesterol oxidase is chosen to be used in further experiment. This indicated that the optimum $\mathrm{pH}$ value of the enzyme may not be affected by immobilization procedure. ${ }^{57}$ These results are compatible with the similar studies in the literature. . $19,21,36,57^{2}$

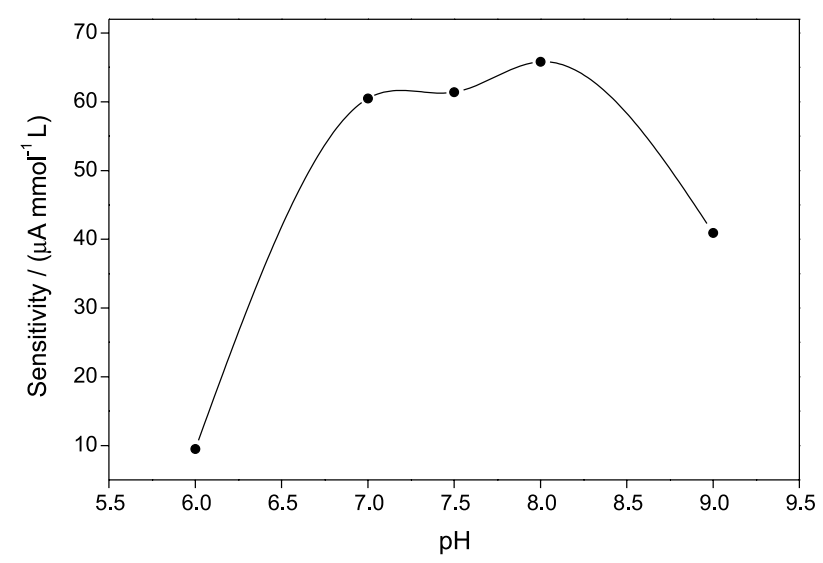

Figure 4. Sensitivity of $\mathrm{Pt} / \mathrm{PoPD} / \mathrm{ChOx}$ electrode as a function of buffer $\mathrm{pH}$ in $0.05 \mathrm{~mol} \mathrm{~L}^{-1}$ phosphate buffer at $+0.7 \mathrm{~V}$ vs. $\mathrm{Ag} / \mathrm{AgCl}$.

\section{Effect of the working temperature}

The evaluation of the temperature dependence on the enzyme electrode performance, calibration curves of the $\mathrm{Pt} / \mathrm{PoPD} / \mathrm{ChOx}$ electrode under temperatures varied from 10 to $50{ }^{\circ} \mathrm{C}$ were plotted and sensitivities were compared in Figure 5. As seen from figure, the sensitivity increases with the increase of temperature up to $40{ }^{\circ} \mathrm{C}$ and beyond this value decrease in the sensitivity is observed. The enzyme is thought to be denatured after this temperature. Although different temperatures were reported as optimum, it was observed that in cholesterol biosensors based on polymer films were carried out at room temperature..$^{21,23}$ For practical applications, following experiments were carried out at room temperature $\left(23 \pm 2{ }^{\circ} \mathrm{C}\right)$.

Reusability, reproducibility, response time and life time

For the evaluation to reusability of $\mathrm{Pt} / \mathrm{PoPD} / \mathrm{ChOx}$, five calibration curves were plotted by using same electrode at $+0.7 \mathrm{~V}$ (vs. $\mathrm{Ag} / \mathrm{AgCl}$ ) sequentially. The relative standard deviation of sensitivities was found to be $4.2 \%$. In addition, the reproducibility of enzyme electrode is investigated to plot calibration curves by using three different enzyme electrodes and the relative standard deviation of sensitivity 


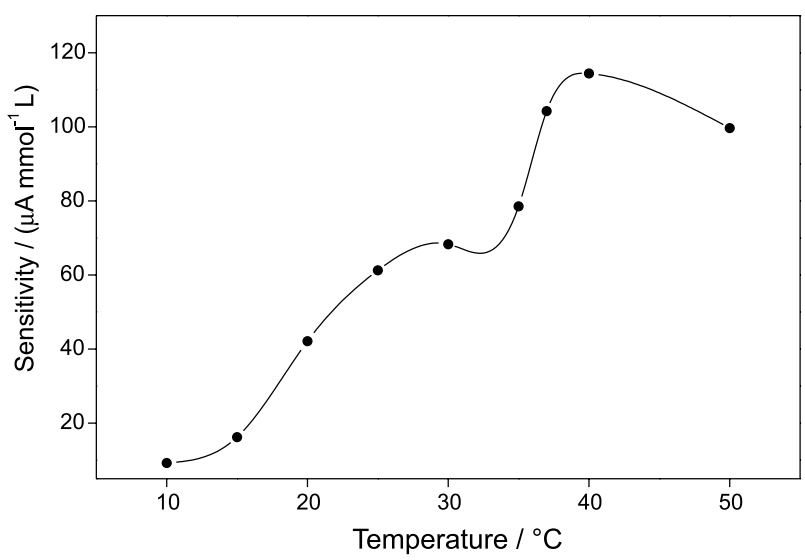

Figure 5. Sensitivity of the $\mathrm{Pt} / \mathrm{PoPD} / \mathrm{ChOx}$ enzyme electrode as function of temperature in $0.05 \mathrm{~mol} \mathrm{~L}^{-1}$ phosphate buffer $(\mathrm{pH} 7.5)$ at $+0.7 \mathrm{~V} v$ s. $\mathrm{Ag} / \mathrm{AgCl}$.

values was found as $5.5 \%$. These results indicate that the reusability and reproducibility of the enzyme electrode were highly satisfactory and the electrode can be used for many analyses.

The response time that is defined as the time it takes for the electrode to reach $95 \%$ of the steady-state current of the $\mathrm{Pt} / \mathrm{PoPD} / \mathrm{ChOx}$ enzyme electrode was determined at two different cholesterol concentrations. The current differences for $1.0 \times 10^{-6} \mathrm{~mol} \mathrm{~L}^{-1}$ and $1.0 \times 10^{-5} \mathrm{~mol} \mathrm{~L}^{-1}$ cholesterol against time were plotted. The response time can be taken as ca. $150 \mathrm{~s}$ in which the currents are approximately constant.

To evaluate the life time and stability of $\mathrm{Pt} / \mathrm{PoPD} / \mathrm{ChOx}$ electrode, amperometric response to cholesterol was measured for two weeks and sensitivity values of electrode were compared. Enzyme electrode retained $41 \%$ of initial sensitivity after six days.

\section{Effect of the cholesterol concentration}

In order to determine the linear working range of the cholesterol enzyme electrode, the amperometric response of the $\mathrm{Pt} / \mathrm{PoPD} / \mathrm{ChOx}$ electrode was recorded as a function of the cholesterol concentration (Figure 6). The two linear working ranges were obtained. The first range was linear from $9.8 \times 10^{-3} \mu \mathrm{mol} \mathrm{L} \mathrm{L}^{-1}$ to $1.1 \times 10^{-1} \mu \mathrm{mol} \mathrm{L} \mathrm{L}^{-1}$ with a regression equation of $y=15.18 x+1.12\left(\mathrm{R}^{2}=0.9826\right)$ and the second one was linear from $1.1 \times 10^{-1} \mu \mathrm{mol} \mathrm{L}^{-1}$ to $11 \mu \mathrm{mol} \mathrm{L}{ }^{-1}$ with a regression equation of $y=0.095 x+2.80$ $\left(\mathrm{R}^{2}=0.9769\right)$. The limit of detection of the biosensor is $9.8 \times 10^{-3} \mu \mathrm{mol} \mathrm{L} \mathrm{L}^{-1}$ and sensitivities of biosensor are $15.18 \mu \mathrm{Amol}^{-1} \mathrm{~L}$ (for the first linear range) and $0.095 \mu \mathrm{A} \mu \mathrm{mol}^{-1} \mathrm{~L}$ (for the second linear range). Normal human blood plasma contains $130-260 \mathrm{mg} \mathrm{dL}^{-1}$ (3.4-6.7 $\mathrm{mmol} \mathrm{L}^{-1}$ ) cholesterol. This range does not cover the normal serum total cholesterol level. The response at lower concentrations is important when working with diluted samples to avoid the interferences. ${ }^{58}$

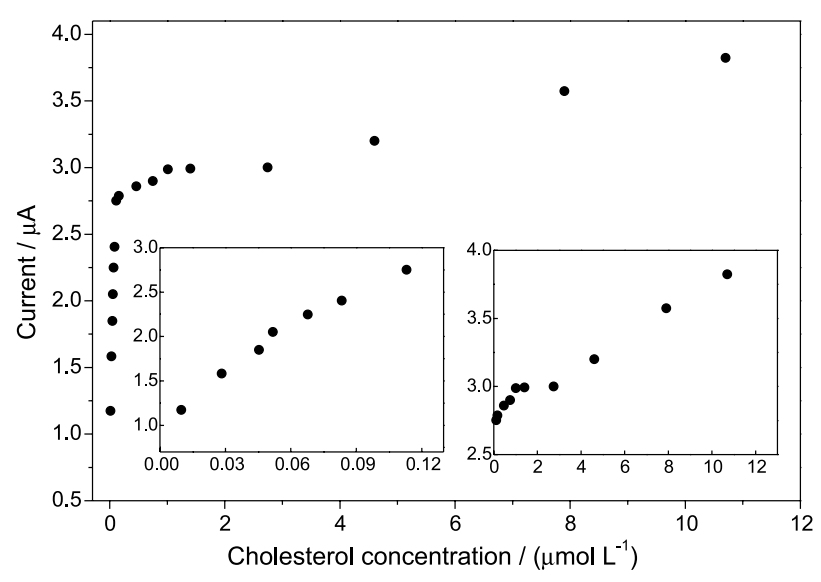

Figure 6. Calibration curve of the $\mathrm{Pt} / \mathrm{P} o \mathrm{PD} / \mathrm{ChOx}$ enzyme electrode for cholesterol in $0.05 \mathrm{~mol} \mathrm{~L}^{-1}$ phosphate buffer $(\mathrm{pH} \mathrm{7.5)}$ at $+0.7 \mathrm{~V}$ vs. $\mathrm{Ag} / \mathrm{AgCl}$.

Interference study

The effects of various interferences (ascorbic acid, glucose, creatinine, paracetamol, urea, aspartic acid and uric acid) which present in blood on $\mathrm{Pt} / \mathrm{P} o \mathrm{PD} / \mathrm{ChOx}$ enzyme electrode response were investigated. The solutions of these substances were added into buffer solution containing $1.0 \times 10^{-3} \mathrm{mmol} \mathrm{L}^{-1}$ cholesterol one by one and current responses at $+0.7 \mathrm{~V}$ (vs. $\mathrm{Ag} / \mathrm{AgCl})$ were recorded. The percentages of interference were determined as the difference in percentage of response between the buffer solution containing cholesterol and interferences and over that of cholesterol. The results were summarized in Table 1 and it can be concluded that uric acid caused $17.6 \%$ interference at the highest concentration in serum. It was reported that dilution reduced the effect of interferences. ${ }^{58}$

Table 1. Interference study

\begin{tabular}{lcc}
\hline Interference & $\begin{array}{c}\text { Concentration } \\
\left(\mathrm{mmol} \mathrm{L}^{-1}\right)\end{array}$ & $\begin{array}{c}\text { Interference }^{\mathrm{b}} / \\
\%\end{array}$ \\
\hline Ascorbic acid & 0.1 & 8.7 \\
Glucose & 4.0 & 9.9 \\
Creatinine & 0.1 & 2.8 \\
Paracetamol & 0.1 & 9.0 \\
Urea & 0.8 & 3.9 \\
Aspartic acid & 0.01 & 3.3 \\
Uric acid & 0.5 & 17.6 \\
\hline
\end{tabular}

${ }^{a}$ Electrochemical cell concentration of interferences; ${ }^{\text {interference }=}$ $\left(I_{x}-I_{0}\right) / I_{0} 100 ; I_{0}$ : amperometric response of buffer solution containing $1.0 \times 10^{-3} \mathrm{mmol} \mathrm{L}^{-1}$ cholesterol solution $\mathrm{I}_{\mathrm{x}}$ : amperometric response of buffer solution containing $1.0 \times 10^{-3} \mathrm{mmol} \mathrm{L}^{-1}$ cholesterol and interferences with above concentration. 
Analysis of the total cholesterol in blood serum

The determination of total cholesterol in serum samples is important for clinical diagnosis of many disorders. Since the two-third of cholesterol in blood is esterified with fatty acids, for the determination of total cholesterol, both cholesterol esterase (ChEt) and cholesterol oxidase enzymes must be used. Cholesterol esterase catalyzes the hydrolysis of the esters by following reaction (equation 3 ):

Cholesterol esters $+\mathrm{H}_{2} \mathrm{O} \stackrel{\text { ChEt }}{\longrightarrow}$ cholesterol + fatty acids

Therefore, for determination of total cholesterol present in serum samples, first, the samples were incubated with cholesterol esterase enzyme at $37^{\circ} \mathrm{C}$ for $10 \mathrm{~min}$ to ensure that all esterified cholesterol was hydrolyzed. A dilution was performed to have the cholesterol concentration inside the working range of the response. Thus, the possible interference caused by the electroactive species present in the serum decreased considerably. ${ }^{27}$ The concentration of total cholesterol of three serum samples were analyzed with the proposed $\mathrm{Pt} / \mathrm{PoPD} / \mathrm{ChOx}$ by standard addition method and results were compared with hospital method (Table 2). The total cholesterol concentrations obtained from analyses of serum samples by both methods were plotted and the following equation was obtained: $y=0.99 x-0.77\left(\mathrm{R}^{2}=0.9997\right)$.

Table 2. Determination of total cholesterol content in serum samples using the proposed enzyme electrode

\begin{tabular}{lcc}
\hline & \multicolumn{2}{c}{ Total cholesterol / $\left(\mathrm{mg} \mathrm{dL}^{-1}\right)$} \\
\cline { 2 - 3 } Serum sample & $\begin{array}{c}\mathrm{Pt} / \mathrm{PoPD} / \mathrm{ChOx} \\
\text { biosensor }^{\mathrm{a}}\end{array}$ & $\begin{array}{c}\text { Spectrophotometric } \\
\text { method }\end{array}$ \\
\hline Sample 1 & $178.50 \pm 2.2$ & 178 \\
Sample 2 & $208.95 \pm 2.9$ & 209 \\
Sample 3 & $229.90 \pm 12.4$ & 229 \\
\hline
\end{tabular}

The results are the mean value of three measurements.

It was also checked the accuracy of the method by student's $t$-test. The $t$-value is 1.63 for $\mathrm{Pt} / \mathrm{PoPD} / \mathrm{ChOx}$ at $95 \%$ confidence level, for which $t_{\text {critic }}$ is 4.30 . It can be concluded that there is no difference between the results of two methods at a confidence level of $95 \%$.

In the literature, various amperometric biosensors have been development for determination of free cholesterol, however in those studies, monitoring of total cholesterol in serum samples has not been performed using above mentioned biosensors. ${ }^{13,17,21,23,36,59}$ In many studies, cholesterol contents of synthetic serum samples like Accutrol $^{\mathrm{TM}}$ were determined. ${ }^{16,35}$ Brahim et al. ${ }^{14}$ reported a amperometric biosensor to the determination of total cholesterol in serum samples with a correlation coefficient of 0.998. Li et al. ${ }^{57}$ used carbon nanotubes modified electrodes for detection of cholesterol in serum samples and correlation coefficient of 0.943 was obtained between proposed enzyme electrode results and those obtained by spectrophotometric method. Basu et al. ${ }^{20}$ developed a cholesterol biosensor for analysis of total cholesterol in food samples like egg and meat and concluded that biosensor showed close results as with the colorimetric method. Our group also demonstrated $\mathrm{Pt} / \mathrm{PoPD} / \mathrm{ChOx}$ biosensor was used for the determination of total cholesterol in serum samples with correlation coefficient of 0.99 .

The characteristics of the some other polymer film based cholesterol biosensors in literature are summarized in Table 3 in order to compare with the proposed poly(o-phenylenediamine) film based cholesterol biosensor. Table 3 clearly shows that the different characteristics of proposed biosensor are better in some cases or comparable with some given cholesterol biosensor. It shown that the limit of detection $\left(9.8 \times 10^{-3} \mu \mathrm{mol} \mathrm{L}^{-1}\right)$ of the $\mathrm{Pt} / \mathrm{PoPD} / \mathrm{ChOx}$ electrode is lower than that of reported for cholesterol biosensors that include $0.4 \mathrm{mmol} \mathrm{L}^{-1}$ for Pt/PEDOP-ChOx electrode, ${ }^{23} 2.5 \mathrm{mg} \mathrm{dL}^{-1}\left(64.8 \mu \mathrm{mol} \mathrm{L}^{-1}\right)$ for PVC/ChOx-ChEt cell containing CPE-HRP electrode, ${ }^{60}$ $0.012 \mathrm{mmol} \mathrm{L}^{-1}$ for Pt/SAM/PB/PPy-ChOx/Nf electrode, ${ }^{24}$ $120 \mu \mathrm{mol} \mathrm{\textrm {L } ^ { - 1 }}$ for Pt/pHEMA/PPy/ChOx electrode, ${ }^{14}$ $14 \mu \mathrm{mol} \mathrm{L}{ }^{-1}$ for Pt/Pt/PPy-ChOx electrode and $12.6 \mu \mathrm{mol} \mathrm{L}^{-1}$ for $\mathrm{Pt} / \mathrm{Pt} / \mathrm{PPy}-\mathrm{ChOx} / \mathrm{PoPD}$ electrode, ${ }^{12} 10.9 \mathrm{mmol} \mathrm{L}^{-1}$ for $\mathrm{Pt} / \mathrm{Pt} / \mathrm{PPy}-\mathrm{ChOx}+\mathrm{FcMc}$ electrode and $12 \mathrm{mmol} \mathrm{L}^{-1}$ for $\mathrm{Pt} / \mathrm{Pt} / \mathrm{PPy}-\mathrm{ChOx}+\mathrm{FMN}$ electrode, ${ }^{27} 1.35 \mu \mathrm{mol} \mathrm{\textrm {L } ^ { - 1 }}$ for

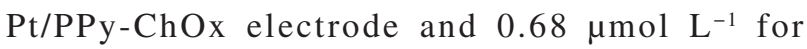
Pt/PPy-ChOx/PoPD electrode..$^{51}$ Also, the working ranges $\left(9.8 \times 10^{-3}-1.1 \times 10^{-1} \mu \mathrm{mol} \mathrm{L^{-1 }}\right.$ and $1.1 \times 10^{-1}$ $11 \mu \mathrm{mol} \mathrm{\textrm {L } ^ { - 1 }}$ ) of the proposed electrode are wider than those of some reported for cholesterol biosensors that contain 0.1-0.5 mmol $\mathrm{L}^{-1}$ for $\mathrm{Pt} / \mathrm{PVF}^{+} \mathrm{ClO}_{4}^{-}-\mathrm{ChOx}$ electrode, ${ }^{21} 50-500 \mathrm{mg} \mathrm{dL}^{-1}$ (1.3-13 $\left.\mathrm{mmol} \mathrm{L}^{-1}\right)$ for ITO/PANI/ChEt/ChOx electrode, ${ }^{17} 1-8 \mathrm{mmol} \mathrm{L}^{-1}$ for Pt/PPy-ChEt-ChOx electrode, ${ }^{33}$ 0.05-0.3 mmol $\mathrm{L}^{-1}$ for $\mathrm{Pt} / \mathrm{SAM} / \mathrm{PB} / \mathrm{PPy}-\mathrm{ChOx} / \mathrm{Nf}$ electrode, ${ }^{24}$ 0.5-15 $\mathrm{mmol} \mathrm{L}^{-1}$ for Pt/pHEMA/PPy/ChOx electrode, ${ }^{14}$ 0.04-0.27 $\mathrm{mmol} \mathrm{L}^{-1}$ for PG/TBMPC-ChOx-HRP electrode, ${ }^{13} 0.01-0.1 \mathrm{mmol} \mathrm{L}^{-1}$ for Pt/PANI-ChOx (1\% Triton X-100) electrode and 0.05-0.2 mmol L ${ }^{-1}$ for Pt/PANI-ChOx (5\% Triton X-100) electrode, ${ }^{3}$ 0.025-0.3 mmol L ${ }^{-1}$ for Pt/PPy-ChOx electrode. ${ }^{35}$ The present biosensor has superiority that it allows to determine in low concentration of cholesterol. Thus, the cholesterol can be analyzed in more dilute samples and the interference effects of the electroactive species present in the serum can be decreased due to the dilution procedure. ${ }^{27}$ 


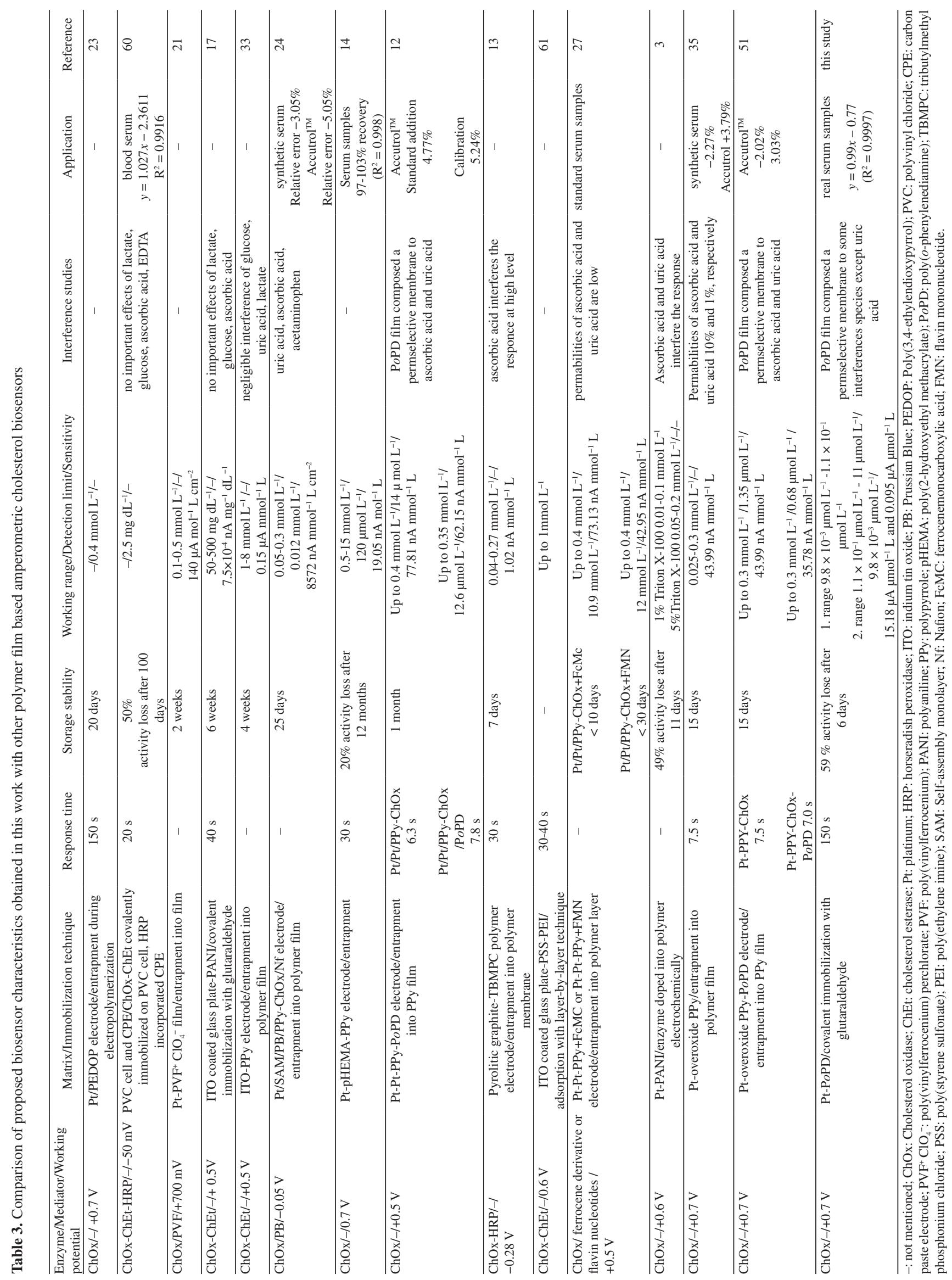


The determination of cholesterol in real samples has not been carried out in the many biosensor studies based on polymer films due to their high limit of detection and effects of interfering species. ${ }^{3,13,17,21,23,36,59,61}$

\section{Conclusions}

In this study, amperometric cholesterol enzyme electrode based on poly (o-phenylenediamine) film was prepared for the determination of total cholesterol content in serum samples. It can be said that electropolymerized poly (o-phenylenediamine) film reduced the interference and $\mathrm{Pt} / \mathrm{PoPD} / \mathrm{ChOx}$ electrode enabled accurate determination of total cholesterol in serum at $+0.7 \mathrm{~V} v s$. $\mathrm{Ag} / \mathrm{AgCl}$. Besides, the proposed enzyme electrode showed very low limit of detection which allows total cholesterol determination in diluted serum samples.

\section{Acknowledgement}

We gratefully acknowledge the financial support (Project No. 106 T 359) of The Scientific and Research Council of Turkey.

\section{References}

1. Waterham, H. R.; FEBS Lett. 2006, 580, 5442.

2. Arya, S. K.; Datta, M.; Malhotra, B. D.; Biosens. Bioelectron. 2008, 23, 1083.

3. Wang, H.; Mu, S.; Sens. Actuators, B 1999, 56, 22.

4. Shih, W.-C.; Yang, M.-C.; Lin, M. S.; Biosens. Bioelectron. 2009, 24, 1679.

5. Manasterski, A. Zak, B.; Microchem. J. 1973, 18, 240.

6. Perlstein, M. T.; Thibert, R. J.; Zak, B.; Microchem. J. 1975, 20, 428.

7. Artiss, J. D.; Thibert, R. J.; Zak, B.; Microchem. J. 1978, 23, 237.

8. Araujo, P.; Couillard, F.; Leirnes, E.; Ask, K.; Bøkevoll, A.; Frøyland, L.; J. Chromatogr., A 2006, 1121, 99.

9. Lin, Y.-T.; Wu, S.-S.; Wu, H.-L.; J. Chromatogr., A 2007, 1156, 280.

10. Hojo, K.; Hakamata, H.; Ito, A.; Kotani, A.; Furukawa, C.; Hosokawa, Y.-Y.; Kusu, F.; J. Chromatogr., A 2007, 1166, 135.

11. Hojo, K.; Hakamata, H.; Kusu, F.; J. Chromatogr., B Anal. Technol. Biomed. Life Sci. 2011, 879, 751.

12. Vidal, J.-C.; García-Ruiz, E.; Castillo, J.-R.; Electroanalysis 2001, 13, 229.

13. Bongiovanni, C.; Ferri, T.; Poscia, A.; Varalli, M.; Santucci, R.; Desideri, A.; Bioelectrochemistry 2001, 54, 17.

14. Brahim, S.; Narinesingh, D.; Guiseppi-Elie, A.; Anal. Chim. Acta 2001, 448, 27.
15. Shumyantseva, V.; Deluca, G.; Bulko, T.; Carrara, S.; Nicolini, C.; Usanov, S. A.; Archakov, A.; Biosens. Bioelectron. 2004, 19, 971.

16. Vidal, J.-C.; Espuelas, J.; Castillo, J.-R.; Anal. Biochem. 2004, $333,88$.

17. Singh, S.; Solanki, P. R.; Pandey, M. K.; Malhotra, B. D.; Anal. Chim. Acta 2006, 568, 126.

18. Salinas, E.; Rivero, V.; Torriero, A. A. J.; Benuzzi, D.; Sanz, M. I.; Raba, J.; Talanta 2006, 70, 244.

19. Solanki, P. R.; Arya, S. K.; Singh, S. P.; Pandey, M. K.; Malhotra, B. D.; Sens. Actuators, B 2007, 123, 829.

20. Basu, A. K.; Chattopadhyay, P.; Roychoudhuri, U.; Chakraborty, R.; Bioelectrochemistry 2007, 70, 375.

21. Özer, B. C.; Özyörük, H.; Çelebi, S. S.; Yıldız, A.; Enzyme Microb. Technol. 2007, 40, 262.

22. Khan, R.; Kaushik, A.; Mishra, A. P.; Mater. Sci. Eng., C 2009, 29, 1399.

23. Türkarslan, Ö.; Kayahan, S. K.; Toppare, L.; Sens. Actuators, B 2009, 136, 484.

24. Vidal, J.-C.; Espuelas, J.; Garcia-Ruiz, E.; Castillo, J.-R.; Talanta 2004, 64, 655.

25. Yıldırımoğlu, F.; Arslan, F.; Çete, S.; Yaşar, A.; Sensors 2009, 9,6435 .

26. Garjonyte, R.; Malinauskas, A.; Sens. Actuators, B 2000, 63, 122.

27. Vidal, J. C.; Garcia-Ruiz, E.; Castillo, J. R.; J. Pharm. Biomed. Anal. 2000, 24, 51.

28. Yang, M.; Yang, Y. ; Yang, Y.; Shen, G.; Yu, R.; Anal. Biochem. 2004, 334, 127.

29. Wang, K.; Xu, J.-J.; Chen, H.-Y.; Biosens. Bioelectron. 2005, 20, 1388 .

30. Garjonyte, R.; Malinauskas, A.; Sens. Actuators, B 1999, 56, 85.

31. Vidal, J.-C.; Garcia-Ruiz, E.; Castillo, J.-R.; Microchim. Acta 2003, 143, 93.

32. Yuqing, M.; Jianrong, C.; Xiaohua, W.; Trends Biotechnol. 2004, 22, 227.

33. Singh, S.; Chaubey, A.; Malhotra, B. D.; Anal. Chim. Acta 2004, $502,229$.

34. Singh, S.; Chaubey, A.; Malhotra, B. D.; J. Appl. Polym. Sci. 2004, 91, 3769.

35. Vidal, J. C.; García, E.; Castillo, J. R.; Anal. Chim. Acta 1999, $385,213$.

36. Singh, S.; Solanki, P. R.; Pandey, M. K.; Malhotra, B. D.; Sens. Actuators, B 2006, 115, 534.

37. Védrine, C.; Fabiano, S.; Tran-Minh, C.; Talanta 2003, $59,535$.

38. Rothwell, S. A.; Killoran, S. J.; Neville, E. M.; Crotty, A. M.; O’Neill, R. D.; Electrochem. Commun. 2008, 10, 1078.

39. Dumont, J.; Fortier, G.; Biotechnol. Bioeng. 1996, 49, 544.

40. Malitesta, C.; Palmisano, F.; Torsi, L.; Zambonin, P. G.; Anal. Chem. 1990, 62, 2735. 
41. Moussy, F.; Harrison, D. J.; O’Brien, D. W.; Rajotte, R. V.; Anal. Chem. 1993, 65, 2072.

42. Myler, S.; Eaton, S.; Higson, S. P. J.; Anal. Chim. Acta 1997, 357, 55.

43. Yasuzawa, M.; Matsuki, T.; Mitsui, H.; Kunugi, A.; Nakaya, T.; Sens. Actuators, B 2000, 66, 25.

44. De Corcuera, J. I. R.; Cavalieri, R. P.; Powers, J. R.; J. Electroanal. Chem. 2005, 575, 229.

45. Vidal, J. C.; Méndez, S.; Castillo, J. R.; Anal. Chim. Acta 1999, 385,203

46. Cosnier, S.; Fombon, J. J.; Labbé, P.; Limosin, D.; Sens. Actuators, B 1999, 59, 134

47. Karalemas, I. D.; Georgiou, C. A.; Papastathopoulos, D. S.; Talanta 2000, 53, 391.

48. Curulli, A.; Kelly, S.; O’Sullivan, C.; Guilbault, G. G.; Palleschi, G.; Biosens. Bioelectron. 1998, 13, 1245.

49. Castañón, M. J. L.; Miranda Ordieres, A. J.; Blanco, P. T.; Biosens. Bioelectron. 1997, 12, 511.

50. Dai, Y.-Q.; Zhou, D.-M.; Shiu, K.-K.; Electrochim. Acta 2006, $52,297$.

51. Vidal, J. C.; García, E.; Castillo, J. R.; Sens. Actuators, B 1999, $57,219$.

52. Zeybek, Bülent. Electrochemical synthesis and applications of some conducting polymers. PhD Thesis, Ankara University, Ankara, Turkey, 2010. http://www.yok.gov.tr/content/ view/59/111/lang,tr/
53. Zambonin, C. G.; Losito, I.; Anal. Chem. 1997, 69, 4113.

54. Lukachova, L. V.; Kotel'nikova, E. A.; D’Ottavi, D.; Shkerin, E. A.; Karyakina, E. E.; Moscone, D.; Palleschi, G.; Curulli, A.; Karyakin, A. A.; Bioelectrochemistry 2002, 55, 145.

55. Hermas, A. A.; Wu, Z. X.; Nakayama, M.; Ogura, K.; J. Electrochem. Soc. 2006, 153, B199.

56. Levin, O.; Kondratiev, V.; Malev, V.; Russ. J. Electrochem. 2008, 44, 98.

57. Li, G.; Liao, J. M.; Hu, G. Q.; Ma, N. Z.; Wu, P. J.; Biosens. Bioelectron. 2005, 20, 2140.

58. Çete, S.; Yaşar, A.; Arslan, F.; Artif. Cells Blood Substit. Biotechnol. 2006, 34, 367.

59. Solanki, P. R.; Kaushik, A.; Ansari, A. A.; Tiwari, A.; Malhotra, B. D.; Sens. Actuators, B 2009, 137, 727.

60. Hooda, V.; Gahlaut, A.; Kumar, H.; Pundir, C. S.; Sens. Actuators, B 2009, 136, 235.

61. Ram, M. K.; Bertoncello, P.; Ding, H.; Paddeu, S.; Nicolini, C.; Biosens. Bioelectron. 2001, 16, 849.

Submitted: May 23, 2012 Published online: January 11, 2013 